\title{
Antimicrobial activities and phytochemical screening of leaf extract of Mikania micrantha H.B.K
}

\author{
Anjana Devkota ${ }^{1} \bowtie$ and Anita Sahu ${ }^{1}$ \\ ${ }^{1}$ Central Department of Botany, Tribhuwan University, Kirtipur Kathmandu, Nepal \\ devkotaa@gmail.com
}

\begin{abstract}
Antimicrobial activities and phytochemical screening of leaves of Mikania micrantha was tested in laboratory against phytopathogenic fungi and human pathogenic bacteria. The leaves samples were extracted in distilled water and methanol. The crude extracts of leaves were assessed in-vitro for antimicrobial activity using different concentrations (50, 100, 150, 200 , and $250 \mathrm{mg} / \mathrm{ml}$ ) against five fungal strains (viz. Sclerotium rolfsii, Phytopthora capsici, Alternaria brassicae, Fusarium oxysporum and Botrytis cinerea) and six bacterial strains (Klebsiella pneumoniae, Proteus mirabilis, Escherichia coli, Bacillus subtilis, Enterococcus faecalis and Staphylococcus aureus). Antifungal activity was tested by Poison Food Technique and Linear Mycelium growth Reduction (LMGR) percentage was determined. In crude extract of $M$. micrantha, the highest LMGR percentage was found in F. oxysporum in both distilled water and methanol extract. Antibacterial activity was carried out by Disc Diffusion method. In the crude leaf extract of $M$. micrantha Gram negative bacteria was found more resistant than Gram positive bacteria. Methanol extract was found more effective in determining the Zone of Inhibition for all the strains of bacteria in all the concentrations. The plant extracts were found more effective in showing antibacterial activity than antifungal activity. The phytochemical screening revealed that the selected species contained tannin, saponins, alkaloid, flavonoid, cardiac glycosides and terpenoids. This result supports the potential of this plant species used as a new chemotherapeutic drug.
\end{abstract}

Keywords: antimicrobial inhibition, mycelium, phytochemical, screening

\section{INTRODUCTION}

Mikania micrantha Kunth ex H.B.K, commonly called mile a minute, is one of the devastating invasive species belonging to family Asteraceae. It is found to be growing best where fertility, organic matter, soil moisture and humidity are high enough. It suppresses the growth of other plants by shading light and smothering them. It is ranked amongst the top three worst invasive weeds of the world (Tiwari et al., 2005). It releases the substances that inhibit the growth of other plants. Extracts of many higher plants have been reported to exhibit antibacterial, antifungal and insecticidal properties under laboratory trails. Plant metabolites and plant based pesticides appear to be one of the better alternatives as they are known to have minimal environmental impact and danger to consumers in contrast to synthetic pesticides (Varma et al., 1999). Mikania species have multiple pharmacological actions. It is used in respiratory tract, anti-inflammatory, anti-allergic, analgesic, antioxidant and in central system 
treatments (Rufatto et al., 2012). ). However, there are no reports about the antimicrobial activities of $M$. micrantha extracts against human pathogenic bacteria and phytopathogenic microorganisms. Hence the present study aimed to identify the potential of $M$. micrantha against human pathogenic bacteria like Klebsiella pneumoniae, Proteus mirabilis, Escherichia coli, Bacillus subtilis, Enterococcus faecalis and Staphylococcus aureus and phytopathogenic microorganisms such as Alternaria brassicae, Botrytis cinerea, Fusarium oxysporum, Phytophthora capsici and Sclerotium rolfsii. Further, it was also aimed to determine important phytochemicals present in the leaf of invasive plant $M$. micrantha, in order to highlight the medicinal values of the plant. Present study may contribute to the continuing search of new natural occurring products with antimicrobial activity and help not only for finding new drug but also for management of invasive plant Mikania micrantha.

\section{MATERIALS AND METHODS}

\section{Collection and processing of the plant sample}

The fresh and healthy leaves of $M$. micrantha were collected from Sauraha, Chitwan, Nepal. The leaves were chopped into small pieces and were shed dried at room temperature. The dried leaves were grinded into fine powder by using electric grinder and were preserved into zipper bag for the further experiment.

\section{Preparation of the extract}

Twenty five grams of the dried ground leaf sample was soaked in $250 \mathrm{ml}$ of distilled water and methanol $(99.99 \%)$ separately for 72 hours. The samples were filtered using three layers of muslin cloth. The solvents distilled water and methanol were evaporated to semisolid form using water bath and rotary evaporator respectively as method followed by Mahida \& Mohan (2007). The obtained semisolid extract was weighted and was kept into air tight container for further analysis.

\section{Phytochemical screening}

Qualitative test: Preliminary qualitative phytochemical screening was carried for the presence of cardio-glycosides, alkaloids, saponins, tannins, flavonoids and terpenoids according to established method of several scientists (Harborne, 1973; Obdoni \& Ochuko, 2001; Sofowora, 1993; Trease \& Evans, 1989)

Qualitative analysis: Preliminary qualitative phytochemical screening was carried out on aqueous and methanol extract applying the standard protocols described by Sofowara (1993), Trease \& Evans (1989), and Harborne (1973) and for the result sharp change in color was noted.

Terpenoids (Salkowski test): Five $\mathrm{ml}$ of each extract was mixed in $2 \mathrm{ml}$ of chloroform, and 3 $\mathrm{ml}$ of concentrated $\mathrm{H}_{2} \mathrm{SO}_{4}$ was added carefully to form a layer. A reddish brown colouration of the interface was formed to show positive results for the presence of terpenoids.

Saponin: One gram of the powered samples were boiled in $10 \mathrm{ml}$ of water and methanol separately in a water bath and filtered. Five $\mathrm{ml}$ of the filtrate was mixed with $2.5 \mathrm{ml}$ of distilled water and shaken vigorously for a stable persistent froth. 
Steroids: Five $\mathrm{ml}$ of extract was taken and to it few drops of acetic anhydride and $5 \mathrm{ml}$ of chloroform was added. Finally few drops of $\mathrm{H} \square \mathrm{SO} \square$ was added slowly along the wall of test tube. Green bluish colour indicated the presence of steroids.

Flavonoids: Five $\mathrm{ml}$ of dilute ammonia solution were added to a portion of the aqueous filtrate of plant extract followed by addition of concentrated $\mathrm{H}_{2} \mathrm{SO}_{4}$ A yellow coloration observed in extract indicated the presence of flavonoids. The yellow coloration disappeared after some time.

Tannins: About $0.5 \mathrm{~g}$ of the dried powered sample was boiled in $20 \mathrm{ml}$ of water in a test tube and then filtered. A few drops of $0.1 \%$ ferric chloride was added and observed for brownish green or a blue-black colouration.

Alkaloid: Plant sample of $200 \mathrm{mg}$ was taken in $10 \mathrm{ml}$ methanol and was filtered. In $2 \mathrm{ml}$ filtrate $1 \% \mathrm{HCL}$ was added and was steamed and $1 \mathrm{ml}$ of filtrate was treated with 6 drops of Mayer's reagents (Mayer's Test). Formation of yellow coloured precipitate indicated the presence of alkaloids. Filtrate was treated with Wagner reagent (Wagner's Test). Formation of brown/ reddish coloured precipitate indicated the presence of alkaloids. Filtrate was treated with Dragondroff's reagents (Dragondroff's Test). Formation of red coloured precipitate indicated the presence of alkaloids.

Cardiac glycosides (Keller- Killin Test): $2.5 \mathrm{~g}$ of powdered sample was soaked in $10 \mathrm{ml}$ of water. $5 \mathrm{ml}$ of extract was treated with $2 \mathrm{ml}$ of glacial acetic acid containing one drop of ferric chloride solution. It was then treated with $1 \mathrm{ml}$ of concentrated sulphuric acid. A brown ring of the interface indicates a deoxysugar characteristic of cardenolides. A violet ring may appear below the ring, while in the acetic acid layer, a greenish ring may form just gradually throughout thin layer.

Quantitative test: Quantitative test was carried out for alkaloids, saponins and flavonoids following the methods of several scientists (Boham et al., 1994; Harborne,1973; Panthi \& Chaudhary, 2006). Quantitative estimation was carried out in crude form.

Alkaloid test (Harborne method 1973):The sample (2.5 g ) was weighed into a $250 \mathrm{ml}$ beaker and $100 \mathrm{ml}$ of $10 \%$ acetic acid in ethanol was added and covered and allowed to stand for 4 hours. This was filtered and the extract was concentrated on a water bath to one-quarter $(25 \mathrm{ml})$ of the original volume. Concentrated ammonium hydroxide was added drop wise to the extract until the precipitate was complete. The whole solution was allowed to settle and the precipitate was collected and washed with dilute ammonium hydroxide and then filtered. The residue was the alkaloid, which was dried and weighed (initial and final weight of the filter paper was calculated).

Saponin determination (Obadoni \& Ochuko, 2001) :The samples were grounded and $10 \mathrm{~g}$ of each were put into a conical flask and $50 \mathrm{~cm}^{3}$ of $20 \%$ aqueous ethanol were added. They were heated over a hot water bath for $2 \mathrm{~h}$ with continuous stirring at about $90^{\circ} \mathrm{C}$. The mixture was filtered and the residue re-extracted with another $100 \mathrm{ml} 20 \%$ ethanol. The combined extracts were reduced to $20 \mathrm{ml}$ over water bath at about $90^{\circ} \mathrm{C}$. The concentrate was transferred into a $250 \mathrm{ml}$ separatory funnel and $10 \mathrm{ml}$ diethyl ether was added and shaken vigorously. The aqueous layer was recovered while the ethyl layer was discarded. The purification process 
repeated. $30 \mathrm{ml}$ of $\mathrm{n}$ - butanol was added. The combined $\mathrm{n}$-butanol extracts were washed twice with $5 \mathrm{ml}$ of $5 \%$ of aqueous sodium chloride. The remaining solution was heated in a water-bath. After evaporation the samples were dried in the oven to a constant wt; the saponin content was calculated as percentage.

Flavonoid determination (Bohm \& Kocipai-Abyazan, 1994): $10 \mathrm{~g}$ of each plant's leaf sample was extracted with $100 \mathrm{ml}$ of $80 \%$ aqueous methanol at room temperature. The solution was filtered through Whatmans filter paper. The filtrate was later transferred into crucible and evaporated in dryness over a water bath and weighted to a constant weight.

\section{Collection and maintenance of test organisms}

Bacterial strains: The bacterial strains used for the test were collected from Department of Microbiology, Teaching Hospital, Maharajgunj, Kathmandu. Six strains, viz. three Gram negative i.e. Klebsiella pneumoniae (ATCC 15380), Proteus mirabilis (ATCC 49132), and Escherichia coli (ATCC 25922) and three Gram positive i.e. Bacillus subtilis (ATCC6633), Enterococcus faecalis (ATCC 29212), and Staphylococcus aureus (ATCC 25923) were used for the test.

Fungal strains: The fungal strains used for study were collected from Nepal Agriculture and Research Council, Khumaltar, Kathmandu. The five strains used for the test were Sclerotium rolfsii, Phytopthora capsici, Alternaria brassicae, Fusarium oxysporum, and Botrytis cinerea.

\section{Preparation of culture inocula}

For bacterial strains: Nutrient broth was prepared with the help of manufacture (Hi-media) recommendation. It was sterilized by autoclaving at $15 \mathrm{lbs}$ pressure and $121^{\circ} \mathrm{C}$ for 2 hours in the conical flask. The cooled $10 \mathrm{ml}$ Nutrient broth was poured in the sterilized Petri plates. The bacterial strain to be tested was aseptically taken with the help of needle from primary cultured slants and was transferred to the Petri plate containing nutrient broth and this was inoculated overnight in the incubator at $37^{\circ} \mathrm{C}$.

For fungus strains: Potato Dextrose Agar (PDA) media was used for the fungal culture. 10 $\mathrm{ml}$ of PDA was poured in the sterilized Petri plate and $4 \mathrm{~mm}$ size of the pure culture from the slant was taken and was carefully placed in an inverted position. This was inoculated in the incubator at $27^{\circ} \mathrm{C}$ for 7 days.

\section{Antibacterial Test}

For bacteria: Inhibition of bacterial growth was tested by using Disc Diffusion Method (Samie \& Nefefe, 2012) with some modifications. 24 hours old bacterial culture was taken in sterilized Petri plates with the help of cotton swab and was suspended in $10 \mathrm{ml}$ distilled water.

Preparation of test discs: $5 \mathrm{~mm}$ test discs were made by using Sartorius stadium (292) filter paper. The discs were prepared by saturating the sterilized filter paper in different concentrations of distilled water and methanol plant extracts $(50,100,150,200,250 \mathrm{mg} /$ $\mathrm{ml}$ ) and control. For negative control (blank), distilled water and methanol paper were used, similarly for positive control antibiotics viz. ampicillin, and monocef were used by saturation the discs into $100 \mathrm{mg} / \mathrm{ml}$ of antibiotics used. 
Preparation of Nutrient Agar and transfer of bacteria: Nutrient Agar (NA) was prepared by following $\mathrm{HI}$ media method. $10 \mathrm{ml}$ media was poured into well labeled and pre-sterilized Petri plates and allowed to solidify for 10-15 minutes. The inoculum of bacteria was spread into Petri plates containing NA using sterile cotton swab. The discs dipped into different concentrations including control were aseptically placed per Petri plates with the help of forceps. After incubation for 24 hours at $37^{\circ} \mathrm{C}$, diameters of inhibition zone around each disc were measured to the nearest millimeter $(\mathrm{mm})$ with a ruler (including $5 \mathrm{~mm}$ diameter of the test discs). The activity of extract was compared with standard antibiotics (ampicillin, monocef). Seven replicates were used for each test.

For fungus: The antifungal activity of plant extracts was determined by using Poisoned Food Technique applying the method of Samie and Nefefe (2012), with some modifications. The concentrations $(50,100,150,200$, and $250 \mathrm{mg} / \mathrm{ml})$ was prepared by using distilled water and methanol crude leaf extract.

Transfer of the fungal strains: A volume of $1 \mathrm{ml}$ the concentration to be used was poured aseptically into $9 \mathrm{ml}$ of PDA and was swirled to mix the content completely. $10 \mathrm{ml}$ of this mixture (PDA and extract) was then poured into the pre sterilized and well labeled Petri plates applying the method of Samie \& Nefefe (2012). It was allowed to solidify for 15-20 minutes. The negative control plates received only distilled water and methanol in PDA without extract, while for positive control, fungiside Bavistin and Mancozeb were used. $4 \mathrm{~mm}$ inoculums from actively growing margin of fungus culture isolate (7 days old culture) was placed face down in the center of the petriplate with the help of sterilized needle. The test fungi were inoculated for 7 days at $27^{\circ} \mathrm{C}$. The fungal colony was measured on the seventh day of incubaton. Minimum and maximum readings of the colony diameter were taken using millimetre ruler. For each treatment seven replicates were used and mean value was taken. The result was compared with the positive control. The percentage of linear mycelium growth reduction of pathogenic fungi compared with control was calculated using the following formula as Khalil \& Dababneh (2012).

Linear growth reduction $(\%)=$ growth in control - growth in treatment/growth in control $\times 100$

\section{RESULTS AND DISCUSSION}

The crude leaf extract yield was found higher in the distilled water $(16.32 \%)$ than methanol (9.2\%) (fig. 1). 
Devkota and Sahu: Antimicrobial activities and phytochemical screening. .279

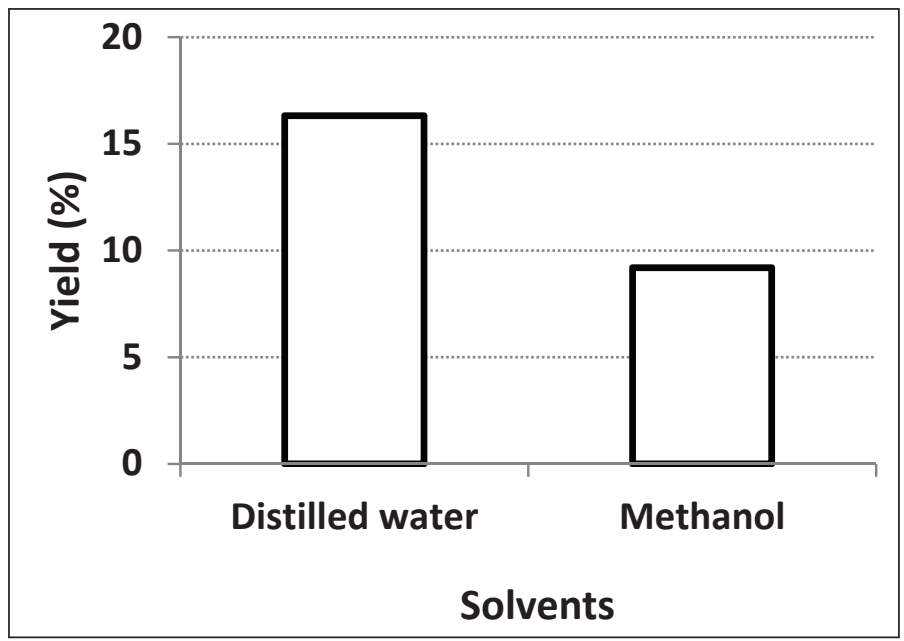

FIG.1. Yield of chemical compounds in different solvents.

Results of preliminary phytochemical screening of leaf extracts of $M$. micrantha showed the presence of important bioactive compounds. It also showed the presence of tannin, saponins, cardiac glycosides, terpenoids, steroids, flavonoids and alkaloids. Cardiac glycosides and steroids were found in greater amount in the methanol solvent (table 1).

TABLE 1. Preliminary phytochemical screening of leaf extract of Mikania micrantha.

\begin{tabular}{|c|c|c|c|c|c|c|c|}
\hline \multirow[b]{2}{*}{ Solvents } & \multicolumn{7}{|c|}{ Phytochemical constituents } \\
\hline & 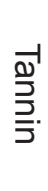 & 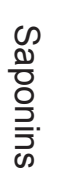 & 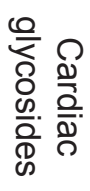 & $\begin{array}{l}\text { D' } \\
\frac{D}{0} \\
\frac{\mathbb{D}}{0} \\
\frac{0}{0} .\end{array}$ & $\begin{array}{l}\frac{C}{\mathbb{D}} \\
\frac{\mathrm{D}}{\mathrm{O}} \\
\frac{\mathrm{O}}{\mathrm{O}}\end{array}$ & $\begin{array}{l}\frac{T}{0} \\
\frac{0}{\alpha} \\
\frac{0}{2}\end{array}$ & $\frac{D}{\frac{D}{\alpha}} \frac{0}{0}$ \\
\hline Methanol & + & ++ & +++ & + & +++ & ++ & + \\
\hline $\begin{array}{l}\text { Distilled } \\
\text { water }\end{array}$ & + & ++ & - & - & - & + & + \\
\hline
\end{tabular}

$+++=$ strong reactions, $++=$ moderate, $+=$ weak, $-=$ no reaction 


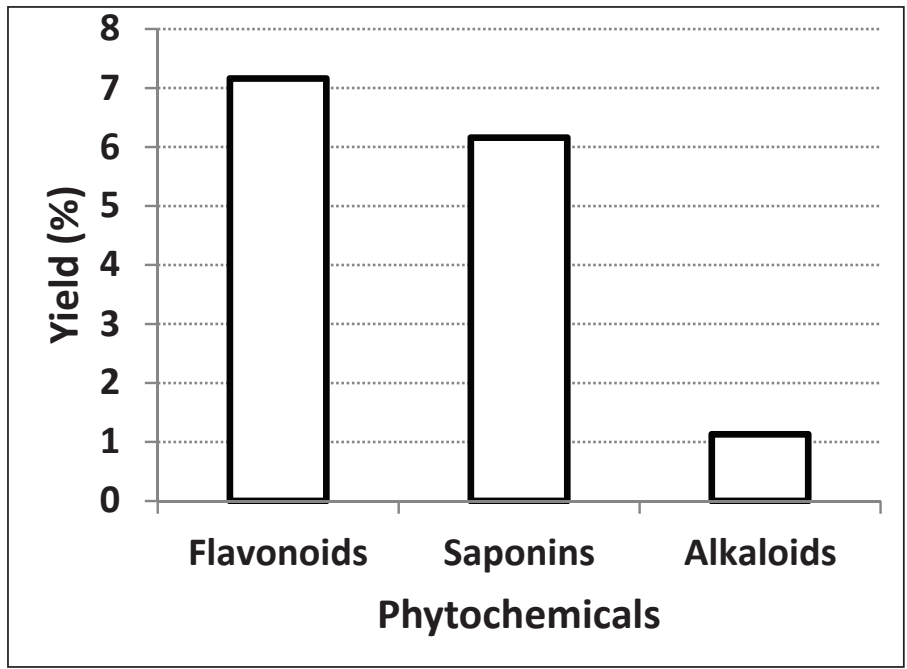

FIG. 2. Yield of different phytochemicals.

Yield of flavonoids was found highest $(7.16 \%)$ followed by saponins $(6.16 \%)$ and alkaloids $(1.13 \%)$ (fig. 2). Highest growth reduction was observed in $F$. oxysporum and $B$. cinerea in bavistin and mancozeb (table 3 ) than in distilled water and methanol (table 2).

TABLE 2. Percentage of linear mycelium growth reduction of different phytopathogenic fungi in distilled water (DW) and methanol (M) crude leaf extract of $M$. micrantha.

\begin{tabular}{|c|c|c|c|c|c|c|c|c|c|c|}
\hline \multirow{3}{*}{ Fungi } & \multicolumn{10}{|c|}{ Linear mycelium growth reduction (\%) } \\
\hline & \multicolumn{2}{|c|}{50} & \multicolumn{2}{|c|}{100} & \multicolumn{2}{|c|}{150} & \multicolumn{2}{|c|}{200} & \multicolumn{2}{|c|}{250} \\
\hline & DW & M & DW & M & DW & M & DW & M & DW & M \\
\hline $\begin{array}{l}\text { Sclerotium } \\
\text { rolfsii }\end{array}$ & 0 & 0 & 0 & 0 & 0 & 24.29 & 0 & 34.29 & 19.64 & 38.71 \\
\hline $\begin{array}{l}\text { Phytopthora } \\
\text { capsici }\end{array}$ & 0 & 0 & 0 & 14.64 & 0 & 17.43 & 0 & 18.79 & 0 & 27.71 \\
\hline $\begin{array}{l}\text { Alternaria } \\
\text { brassicae }\end{array}$ & 33.96 & 18.98 & 41.49 & 25.62 & 45.84 & 29.00 & 47.33 & 33.24 & 57.53 & 43.68 \\
\hline $\begin{array}{l}\text { Fusarium } \\
\text { oxysporum }\end{array}$ & 62.04 & 36.16 & 66.70 & 40.78 & 69.40 & 50.00 & 79.76 & 55.30 & 81.90 & 64.75 \\
\hline $\begin{array}{l}\text { Botrytis } \\
\text { cinerea }\end{array}$ & 29.44 & 16.23 & 32.89 & 19.48 & 41.91 & 30.52 & 46.68 & 41.23 & 54.91 & 46.75 \\
\hline
\end{tabular}

$0=$ no action / no growth reduction, values are mean of seven replica. 
Devkota and Sahu: Antimicrobial activities and phytochemical screening.....

TABLE 3. Reduction in mycelium growth $(\mathrm{mm})$ in negative and positive controls.

\begin{tabular}{|l|c|c|c|c|}
\hline \multirow{2}{*}{\multicolumn{1}{|c|}{ Fungi }} & \multicolumn{2}{|c|}{ Negative control (blank) } & \multicolumn{2}{c|}{$\begin{array}{c}\text { Positive control } \\
\text { (fungicide) }\end{array}$} \\
\cline { 2 - 5 } & $\begin{array}{c}\text { Distilled } \\
\text { water }\end{array}$ & Methanol & Bavistin & Mancozeb \\
\hline Sclerotium rolfsii & 100 & 100 & 46.5 & 21.42 \\
\hline Phytopthora capsici & 100 & 100 & 100 & 32.57 \\
\hline Alternaria brassicae & 72.14 & 50.60 & 44.85 & 21.35 \\
\hline Fusarium oxysporum & 76.57 & 31 & 13 & 15.35 \\
\hline Botrytis cinerea & 26.92 & 22 & 16 & 13.42 \\
\hline
\end{tabular}

Values are mean of seven replica.

The percentage reduction in mycelium was higher in methanol than in distilled water extract. The significant difference ( $p>0.05)$ was found in effect for the two solvents. In distilled water and methanol the highest reduction was found for $F$. oxysporum and least i.e. No reduction was found for $S$. rolfsii in distilled water and $P$. capsici in methanol (table 2).

There was significant difference $(p>0.05)$ between the two solvents at different concentrations. The highest percentage of linear mycelium growth reduction in distilled water was found in F. oxysporum ( $81.89 \%$ ) followed by A. brassicae $(57.53 \%$ ) and B. cinerea $(54.91 \%)$. In case of $S$. rolfsii percentage reduction (19.64\%) was observed only at $250 \mathrm{mg} / \mathrm{ml}$, while for $P$. capsisi no reduction was observed in distilled water. For methanol extract $F$. oxysporum had the highest percent growth reduction in all concentrations. $B$. cinerea had second highest reduction from $150-250 \mathrm{mg} / \mathrm{ml}$ but its reduction $(16.22$ and $19.48 \%$ ) at $50 \mathrm{mg} / \mathrm{ml}$ and 100 $\mathrm{mg} / \mathrm{ml}$ was lower than $A$. brassicae, similarly $A$. brassicae had 18.98 , and $25.61 \%$ reduction at $50 \mathrm{mg} / \mathrm{ml}$ and $100 \mathrm{mg} / \mathrm{ml}$ while other values are lower $(29 \%, 33.24 \%, 43.68 \%)$ than $B$. cinerea which was found $30.52,41.23$, and $46.75 \%$ at 150,200 and $250 \mathrm{mg} / \mathrm{ml}$, respectively. The growth reduction of $24.26,34.29$, and $38.71 \%$ for S. rolfsii was observed at 150,200 , and $250 \mathrm{mg} / \mathrm{ml}$, respectively while no growth reduction was found at 50 and $100 \mathrm{mg} / \mathrm{ml}$ concentrations. P. capsici showed least percent in the growth reduction $(14.64,17.43,18.79$, and $27.71 \%$ ) at different concentrations used while no growth reduction was observed in 50 $\mathrm{mg} / \mathrm{ml}$ concentration.

There was significant difference ( $p>0.05$ ) between the effect of two solvents used. The crude leaf extract of $M$. micrantha at all concentrations was found more effective than bavistin in reducing the mycelium growth of $A$. brassicae (table 3 ). For $F$. oxysporum the concentrations at $200 \mathrm{mg} / \mathrm{ml}$ for distilled water and $150 \mathrm{mg} / \mathrm{ml}, 200$ and $250 \mathrm{mg} / \mathrm{ml}$ for methanol were more effective in reducing mycelium growth than bavistin and mancozeb. Similarly, for $B$. cinerea the reduction in the growth was found more at 150, 250, 200 and $250 \mathrm{mg} / \mathrm{ml}$ concentrations for both distilled water and methanol than bavistin, in the same way $200 \mathrm{mg} / \mathrm{ml}$ of methanol and $250 \mathrm{mg} / \mathrm{ml}$ of distilled water and methanol was found inhibiting the growth more than mancozeb (table 3). Methanol extract was found more effective than distilled water for all the concentrations. 
J. Nat. Hist. Mus. Vol. 30, 2016-18

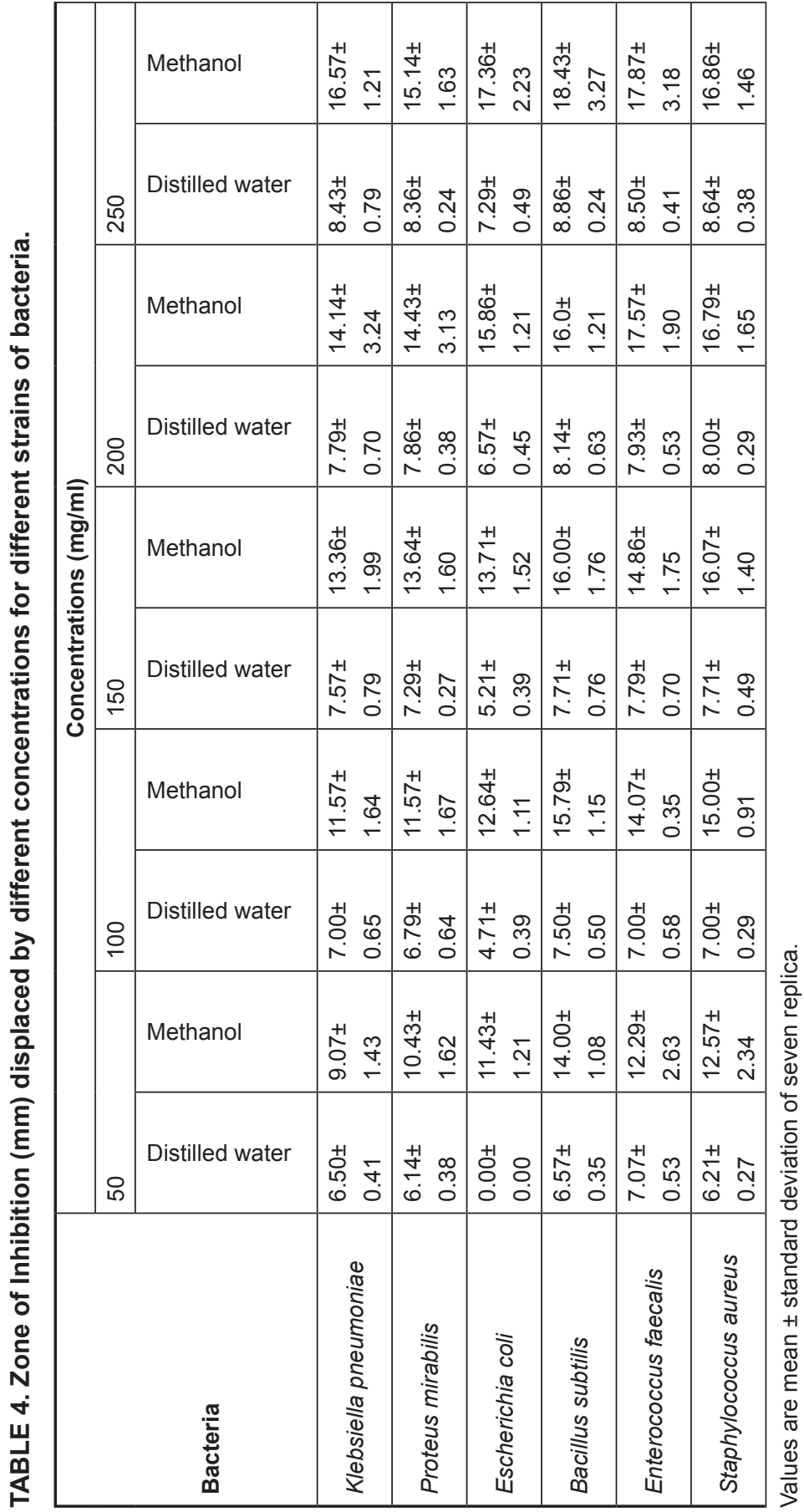


Negative control (distilled water and methanol) did not show any action against bacterial strains. Among the positive control, ampicillin was more effective than monocef for different bacteria used. The plant extract at the concentration used were found less effective than the standard antibiotics in inhibiting the growth of the different strains of the test bacteria used in the study (table 5).

TABLE 5. Zone of inhibition displaced by negative and positive controls.

\begin{tabular}{|c|c|c|c|c|c|}
\hline \multirow[b]{2}{*}{ Type of strains } & \multirow[b]{2}{*}{ Bacteria } & \multicolumn{2}{|c|}{$\begin{array}{c}\text { Negative } \\
\text { control (Blank) }\end{array}$} & \multicolumn{2}{|c|}{$\begin{array}{c}\text { Positive control } \\
\text { (Antibiotics) }\end{array}$} \\
\hline & & 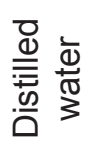 & 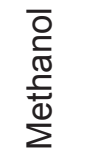 & $\frac{. \sqsubseteq}{\overline{\bar{O}}}$ & 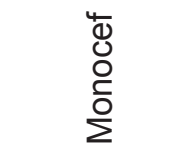 \\
\hline \multirow{3}{*}{ Gram negative } & $\begin{array}{l}\text { Klebsiella } \\
\text { pneumonia }\end{array}$ & NA & NA & $37.79 \pm 4.89$ & $28.1 \pm 3.87$ \\
\hline & Proteus mirabilis & NA & NA & $27.14 \pm 1.31$ & $34.43 \pm 4.41$ \\
\hline & Escherichia coli & NA & NA & $33.21 \pm 4.06$ & $29.64 \pm 3.45$ \\
\hline \multirow{3}{*}{ Gram positive } & Bacillus subtilis & NA & NA & $28.57 \pm 7.44$ & $29.71 \pm 4.46$ \\
\hline & $\begin{array}{l}\text { Enterococcus } \\
\text { faecalis }\end{array}$ & NA & NA & $34.57 \pm 0.45$ & $29.07 \pm 3.17$ \\
\hline & $\begin{array}{l}\text { Staphylococcus } \\
\text { aureus }\end{array}$ & NA & NA & $26.86 \pm 7.73$ & $28.29 \pm 3.99$ \\
\hline
\end{tabular}

Values are mean \pm standard deviation of seven replica.

In different concentrations of distilled water extract gram positive bacteria were found more susceptible than Gram negative bacteria. $B$. subtilis was found most susceptible with largest ZOI among Gram positive bacteria, while E. coli was found most resistant bacteria among Gram negative bacteria at different concentration in distilled water extract (table 4). In methanol leaf extract, $B$. subtilis showed the largest ZOI $(18.43 \mathrm{~mm})$ and smallest for $E$. faecalis among Gram positive bacteria while among Gram negative bacteria $E$. coli had the largest ZOI (17.36 $\mathrm{mm}$ diameter) and $K$. pneumoniae had the smallest ZOI (16.57 $\mathrm{mm}$ diameter). B. subtilis was the most susceptible while K. pneumoniae was the most resistant bacteria for methanol extract.

The higher yield of crude extract was in distilled water (16.32 \%) than methanol (9.2\%) (fig.1). Successive isolation of chemical compounds from the plant material is largely dependent on the type of solvent used in the extraction procedure (Aiyegroro \& Okoh, 2010). Analysis of the preliminary phytochemical screening of leaf extract of $M$. micrantha revealed the presence of phytochemicals such as, tannins, flavonoids, saponins, cardiac glycosides, steroids, terpenoids, and alkaloids (table 1). This result is in accordance with the finding of Matawali et al. (2016). The quantitative analysis showed that the leaf contained highest percentage of 
flavonoid $(7.16 \%)$ followed by saponins $(6.16 \%)$ and alkaloid (1.14\%) (fig.2). This result is similar to the findings of Salah (1995). The phenolic compounds are one of the largest and most ubiquitous groups of plant metabolites (Just et al., 1998). Flavonoids are synthesized by plants in response to microbial infection and they have been found to be antimicrobial substances against wide array of microorganism in vitro (Sodipo et al., 2000). Saponins are known to produce inhibitory effect on inflammation and have property of precipitating and coagulating red blood cells (Okwu, 2001). Steroids have antibacterial properties (Antherden, 1969) and they are very important compounds especially due to their relationship with compounds such as sex hormones (Stray, 1998). Some workers have reported the analgesic (Okwu \& Okwu, 2004) antispasmodic and antibacterial (Nyarko \& Addy, 1990) properties of alkaloids. Glycosides are known to lower the blood pressure according to many reports. Phytochemical analysis conducted on the plant extracts revealed the presence of constituents which are known to exhibit medicinal as well as physiological activities (Sofowora, 1993).

This study reveals that leaf extract of $M$. micrantha has different degrees of inhibition against different test microorganisms at different concentrations (tables 4, 5). The diameter of zone of inhibition produced depends on extrinsic parameters like $\mathrm{pH}$ of the medium, period and temperature of incubation, volume of the well, concentrations of the plant extracts and size of the inoculums can be fixed and standardized during the experiment, hence no error results due to extrinsic factors. However, intrinsic factors such as nature of the medicinal plants including its components, solubility and diffusing property are predetermined. Due to variable infusibility, the antibacterial with very high potency may not determine ZOI commensurate to its efficacy (Farnsworth, 1993).

Comparing effects on Gram positive and Gram negative bacteria, the maximum ZOI (table 4) was displaced by Gram positive bacteria (B. subtilis, E. faecalis and $S$. aureus) than by gram negative bacteria (K. pneumoniae, P. mirabilis and $E$. coli) in both distilled water and methanol extracts. Similarly, various workers have already shown that gram positive bacteria are more susceptible towards plant extracts as compared to gram negative bacteria (Gatsing et al., 2010; Aiyegroro \& Okoh, 2010). These differences may be attributed to fact that the cell wall in Gram positive bacteria is of a single layer, whereas gram negative cell wall is multilayered structure (Yao et al., 1995). Microorganisms show variable sensitivity to chemical substances related to different resistant levels between strains (Cetin \& Gurler, 1989).

Similarly, negative control (distilled water and methanol) did not show any action against the test bacteria. For the antibiotics, K. pneumonia showed the largest ZOI $(37.79 \mathrm{~mm})$ in ampicillin, but had the lowest ZOI $(28.1 \mathrm{~mm})$ in monocef while $P$. mirabilis had lowest $\mathrm{ZOI}$ $(27.14 \mathrm{~mm})$ in ampicillin and largest $(34.34 \mathrm{~mm})$ in monocef. The plant extract showed lower antibacterial activity than the standard antibiotics used. This may be due to the reason that active compound(s) may be present in insufficient quantities in the crude extracts to show activity with the dose levels employed (Taylor et al., 2001). Lack of activity can only be proven by using large doses (Farnsworth, 1993). The plant extracts were found more effective in showing antibacterial activity than antifungal activity. The resistance of fungi to the tested extracts may be due to the presence of more complex cell wall with rigidity than the thin cell membrane of bacteria. Also, this may be due to their ability to produce extracellular enzymes 
that helps them to degrade and metabolize substrate such that the extract becomes a source of food to the fungi instead of inhibiting their growth after they have been rendered nontoxic due to degradation (Gatsing et al., 2010).

The extracts were found effective against the fungal pathogens and human pathogenic bacteria that may be due to the presence of different bioactive compounds in the plants and their action towards the pathogens. The methanolic extracts of plants provided more consistent antimicrobial activity compared to those extracted by distilled water. This might have resulted from lack of solubility of the active constituents in the aqueous solutions while methanol extract showed some degree of antibacterial activity. The distilled water and the methanol leaf extract of $M$. micrantha exhibited antibacterial and antifungal properties with the presence of various phyto-constituents such as alkaloids, tannins and polyphenols, saponins and triterpenoids. The methanolic extracts of plants provided more consistent antimicrobial activity compared to those extracted by distilled water. It was proven that $M$. micrantha offered roles as good antimicrobial agents. This preliminary study had paved a way in effort to discover new and nobel therapeutic antimicrobial. This study help not only for finding new drug but also for proper management of invasive plant Mikania micrantha.

\section{ACKNOWLEDGEMENTS}

We are thankful to University Grants Commission, Nepal, for providing financial support for this research work. We are also grateful to National Agricultural Research Council, Khumaltar and Microbiology Department of Teaching Hospital providing tested microorganisms.

\section{REFERENCES}

AIYEGRORO, O A; OKOH A I (2010) Preliminary phytochemical screening and in vitro antioxidant activities of aqueous extract of Helichrysum longifolium. BMC Complementary and Alternative Medicine 10:21-32.

ANTHERDEN, L M (1969) Textbook of pharmaceutical chemistry. Oxford University Press, London, UK (8th edition).

BOHAM, B A; KOCIPAI-ABYAZAN, R (1994) Flavonoids and condensed tannin from leaves of Hawaiian Vccinium vaticulatum and $V$. calycinium. Pacific scientific 48: 458-463.

CETIN, T E; GURLER, N (1989) Bacterilerin antibiyotiklere duyaarlilik deneyinin yapitnasi. Kukem Dergisi 12: $2-5$.

FARNSWORTH, N R (1993) Biological approaches to the screening and evaluation of natural products. In RASOANAIVO, P; RATSIMAMANGA-URVERG, S (eds) Biological evaluation of plants with reference to the Malagasy flora, Madagascar. pp 35-43.

GATSING, D; NKEUGOAUAPI, C F N; NKAH, B F N; KUIATE, J R; TCHOUANGUEP, F M (2010) International Journal of Pharmacology 6: 173-182.

HARBORNE, J B (1973) Phytochemicals methods. Chapman and Hall Ltd., London, UK.

JUST, J; RECIO, M J; GINER, R M; CUÉLLAR, M J; MÁÑEZ, S; BILLIA, A R; RIOS, J L (1998) Antiinflammatory activity of unusual lupine saponins from Bupleurum fruticescens. Planta Medica 64: 404-407.

KHALIL, A; DABABNEH, B F (2007) Inhibition of phytopathogenic fungi by extracts from medicinal plants 
in Jordan. Journal of Biological Science 7(3): 579-581.

MATAWALI, A; CHIN, L P; ENG, H S; GANSAU, J A (2016) Antibacterial and phytochemical investigations of Mikania micrantha H.B.K. (Asteraceae) from Sabah, Malaysia. Transactions on Science and Technology 3(1-2): 244-250.

MAHIDA, Y; MOHAN, J S (2007) Screening of plants for their potential antibacterial activity Staphylococcus and Salmonella spp. Natural Product Radiance 6(4): 301-305.

NYARKO, A A; ADDY, M E (1990) Effects of aqueous extract of Adenia cissampeloides on blood pressure and serum analyte of hypertensive patients. Phytotherapy Research 4(1): 25-28.

OKWU, D E (2001) Evaluation of chemical composition of medicinal plants belonging to Euphorbiaceae. Pakistan Veterinary Journal 14: 160-162.

OKWU, D E; OKWU, M E (2004) Chemical composition of Spondias mombin Linn. plant parts. Journal of Environment \& Sustainable Agriculture 6(2): 140-147.

OBDONI, B O; OCHUKO, P O (2001) Phytochemical studies and comparative efficacy of the crude extracts of some homostatic plants in Edo and Delta States of Nigeria. Global Journal of Pure and Applied Science 8(b): 203-208.

PANTHI, M P; CHAUDHARY, R P (2006) Antibacterial activity of some selected folklore medicinal plants from West Nepal, Scientific World 4( 4): 16-21.

RUFATTO, L C; GOWER, A; SCHWAMBACH, J; MOURA, S (2012) Genus Mikania: chemical composition and phytotherapeutical activity. Brazilian Journal of Pharmacognosy 22(6): 1384-1403.

SAMIE, A; NEFEFE, T (2012) Antifungal activities of essential oils from Southern African medicinal plants gainst five Fusarium species. Journal of Medicinal Plants Research 6(3):465-478.

SALAH, N, MILLER, N J ; PAGANGA, G; TIJBURG, L; BOLWELL, G P; RICE- EVANS, C (1995) Polyphenolic flavonoids as scavengers of aqueous phase radicals as chain-breaking antioxidant. Archives of Biochemistry and Biophysics 322:339-346

SODIPO, OA; AKINIYI, JA; OGUNBAMORU, JV (2000) Studies on certain characteristics of extracts of bark of Pansinystalia macruceras (K. Schemp) Pierre Exbeille. Global Journal of Pure and Applied Science 6: 83-87.

SOFOWORA, A (1993) Medicinal plants and traditional medicine in Africa. Spectrum Books Ltd., Ibadan, Nigeria.

STRAY, F (1998) The natural guide to medicinal herbs and plants. Tiger Books International, London, UK.

TAYLOR, J L S; RABE, T; MACGRAWL, L J; JAGER, A K; VAN STADEN, J (2001) Towards the scientific validation of traditional medicinal plants. Plant Growth Regulator 34: 23-27.

TIWARI, S; SIWAKOTI, M; ADHIKARI, B; SUBEDI, K (2005) An inventory and assessment of invasive alien plant species of Nepal. IUCN, The World Conservation Union, Nepal.

TREASE, G E; EVANS, W C (1989) Pharmacognosy. Bailliere Tindall, London, UK (11th edition).

VARMA, J; DUBEY, K (1999) Prospectives of botanical and microbial products as pesticides of tomorrow. Current Science 76: 172-179.

YAO, J; MOELLERING, R (1995) Antibacterial agents. In MURRAY, P; BARON, E; PFALLER, M; TENOVER, F; YOLKEN, R; ASM, (eds) Manual of Clinical Microbiology. ASM Press; Washington DC, USA; pp 1281-1290. 